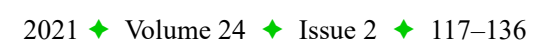

DOI: $10.33223 / \mathrm{epj} / 135830$

\title{
Willingness to pay for the renewable energy sources of the residents of Kraków and their perception of the actions aimed at reducing the level of environmental pollution
}

ABSTRACT: Implementing energy transformation through the goal of the more extensive use of renewable energy sources is one of the key tasks on the road to slowing adverse climate change. The pace of this transformation is dependent on both the political decisions and social support for the implemented changes. The indicator of the aforementioned support is the Willingness to Pay for Renewable Energy Sources (WTP) declared by residents. The increase of the WTP value influences a more rapid and wider substitution of non-renewable energy sources with renewable energy sources. The goal of this paper is to analyze the determinants of the WTP indicator on the example of residents of Kraków and their perception of the actions aimed at reducing the level of environmental pollution. Research is based on a survey performed on a representative sample of 393 residents of Kraków, Poland. In the surveyed group of residents, the average monthly willingness to pay more for renewable energy was PLN 83.7, i.e. approx. USD 21.47. The WTP differs in a statistically significant manner depending on the type of housing in which the respondents reside. On average, the residents

Corresponding Author: Łukasz Mamica; e-mail: mamical@uek.krakow.pl

1 Department of Public Economics, Cracow University of Economics, Kraków, Poland; ORCID iD: 0000-0001-6823-8195; e-mail: mamical@uek.krakow.pl

2021. The Author(s). This is an open-access article distributed under the terms of the Creative Commons Attribution-ShareAlike International License (CC BY-SA 4.0, http://creativecommons.org/licenses/by-sa/4.0/), which permits use, distribution, and reproduction in any medium, provided that the Article is properly cited. 
of detached houses or terraced housing declared the WTP value twice as high as the WTP value declared by the residents of apartment buildings or tenement houses.

KEYWORDS: willingness to pay, energy transformation, eco-friendly attitudes, energy policy

\section{Introduction}

The influence of greenhouse gases, which are produced mainly by burning fossil fuels, on Earth's warming climate stimulates the need for undertaking decisive restorative actions in this area (Hertzberg et al. 2017; Lu 2017). In the majority of instances, renewable energy is more expensive than the energy from non-renewable sources, the development of the former requires co-financing (Shen et al. 2020). The Willingness to Pay for Renewable Energy Sources (WTP) is utilized as a synthetic indicator of the social acceptance for this type of actions. Obviously, in order to achieve meaningful change, like in other countries, support at the level of the national government is necessary (Hess and Gentry 2019). The residents of Kraków, Poland, were chosen as the group covered with the interview survey concerning WTP and residents' opinion on the subject of the undertaken actions aimed at improving the city's air quality and other ecological issues. The choice was due to the fact that the solutions regarding the above-mentioned issues, the first in the entire nation, were introduced in Kraków. The contingent valuation method used in the studies is the most frequently used research method for assessing the WTP in developed economies (Oerlemans et al. 2016).

\section{Background}

\section{WTP - a definition}

The WTP is the amount which households are willing to additionally pay per month over the price of energy they are currently paying. The increase of the WTP value influences the more rapid and wider substitution of non-renewable energy sources with renewable energy sources (RES). The resulting decrease in greenhouse gas emissions reduces the rate of climate change and decarbonizing electricity generation is the key component for cost-effective support of this process (IPCC 2014).

The WTP may be treated as an indicator describing the support for energy transformation and, despite the fact that it refers to a declaration, by merit of indicating actual sums, it can be treated as more credible than any other, generic expressions of support. The pressure for converting to renewable energy sources is further magnified by the nearly $50 \%$ increase in world energy 
consumption in the period of 2018-2050, forecast by the U.S. Energy Information Administration (EIA 2019). Taking climate change occurring currently into consideration, which is related to the level of energy consumption and its current production structure, it seems that the present model is impossible to maintain without the threat of irreversible climate change (Hertzberg et al. 2017). However, the WTP is only a support indicator for energy transformation whereas delivering effects in this area and stopping climate change requires taking simultaneous actions at the government level concerning energy saving strategies and mitigation measures for greenhouse gas emissions (Halkos and Gkampoura 2020). Public administration, operating under the neo-weberian paradigm, through analyzing the WTP level (Mamica 2018), has an opportunity to more efficiently expend public funds on supporting sustainable energy, which should not supplant declared private funding.

The WTP should also be treated as a sign for policymakers establishing the premises of energy policy concerning social consent for the rate and costs of the implemented energy transformation. The development of the Renewable Energy Sources (RES) sector still requires public funding assistance, which can take place with support from public opinion. Owing to the continuously decreasing costs of producing energy from renewable sources, including the fastest decreasing costs of producing energy through the use of solar photovoltaics (Trancik and Cross-Call 2013; Comello et al. 2018), the declared WTP may translate into faster achievement of the established goals of energy policy. Opinions already exist that the current solar photovoltaics and wind technologies are cost-competitive in relation to traditional methods of energy production based on non-renewable energy sources (Ray 2019).

A similar function of monitoring the support for development of RES is served by the "willingness to accept" (WTA) the expected rates of return indicator related to participation in community-based renewable energy projects. The research in this field conducted in South Korea showed that even if people give RES-related investments preferential treatment, they may protest the locating of renewable energy power plants in their neighborhood (Woo et al. 2019). In order to estimate the support for actions in the field of limiting climate change, apart from the WTP for green energy, the willingness-to-pay and willingness-to-accept negative externalities and outcomes of the carbon capture and storage indicators are also being used (Kashintseva et al. 2018).

\section{The WTP value}

A meta-analysis covering 30 studies from 13 countries published on or after the year 2000, indicated inconsistencies in the value of this indicator (the standardized monthly WTP in USD) with the difference between the lowest and the highest value of this indicator being more than USD 53 and the average WTP being USD 7.16 (Soon and Ahmad 2015). Among the three continents where analyzed countries were located, the highest average WTP was noted in the US USD 11.14, Europe - USD 6.80 and Asia - USD 2.28. The highest WTP value in the amount of USD 52.38 was displayed in the studies performed in the US (Li et al. 2009) and the lowest, in the negative - USD -0.37, in Norway (Navrud and Bråten 2007).

The negative value of WTP may be the result of various factors. For instance, in the group of Beijing residents covered by the studies $46 \%$ of respondents declared a negative WTP for 
renewable electricity, providing the following reasons, in order: low income, the belief that the government should be responsible for the issue and the lack of faith that money will be used for reaching this very goal (Guo et al. 2014). In the case of consumers not displaying sufficient willingness to pay for green energy, public funding should be used for the development of these technologies (Bigerna and Polinori 2014). The negative WTP value can also be interpreted as the amount of subsidies, which would induce consumers to convert to the use of renewable energy sources. Campaigns showcasing the significance of renewable energy impact on alleviating climate change increases the chances for WTP growing among the addressees of the campaign (Zhang et al. 2019). However, the interpretation of study results should be approached with caution, because for the US itself the differences in WTP fluctuate between USD 5.05 (Vossler et al. 2003) to approximately USD 44 ( $\mathrm{Li}$ et al. 2009). For Turkish households the mean value of WTP for green electricity was estimated at the level of approximately USD 1 per month (Dogan and Muhammad 2019). The willingness to pay more for the energy from renewable sources is sometimes presented as a percentage. For instance, German electricity consumers have declared the willingness to pay $16 \%$ more for the energy from renewable sources (Kaenzig et al. 2013). In Korea consumers are willing to pay $15.6 \%$ more for the fuel containing $5 \%$ of bio-ethanol, in comparison to conventional gasoline due to the role this type of fuel plays in mitigating greenhouse gas emissions ( $\operatorname{Lim}$ et al. 2017). In the event of supplanting the residential natural gas, a fossil fuel which relies on imports, with renewable methane from bio-gas, the residents of South Korea are willing to pay even $31.9 \%$ more (Kim et al. 2020).

The WTP can also be measured by posing questions concerning the willingness to pay for the research on developing sustainable energy. For instance, Myanmar residents are willing to pay an additional USD 1 per month per household for the research and development of solar energy (Han and Cudjoe 2020). In turn, Beijing residents have declared the WTP per month for solar energy research and development at the level of CNY 5.85 i.e. USD 0.8 (Jin et al. 2019). Research on new renewable energy sources is significant not only due to the need for perfecting the existing methods but also due to the need for developing entirely new and unusual sources such as the algal feedstocks, which have a major chance of being used as a "drop-in" fuel (Levitan et al. 2014).

\section{The WTP - determinants and motifs}

Consumers with strong environmental concerns are willing to pay a premium for renewable fuels in order to reduce greenhouse gas emissions (Marra et al. 2012). The studies conducted among the residents of the Netherlands indicated that the WTP indicator is associated with understanding and worry and this association is stronger when accompanied by hope (Pleeging et al. 2020). The concerns related to the use of non-renewable energy sources are connected to the adverse effect of air pollution on health (Tainio et al. 2020). The increase of the WTP for Renewable Energy Sources (RES) among the interviewed residents of Crete was influenced by high family income and the size of residence, better access to the energy-related information and the higher level of awareness concerning climate change (Zografakis et al. 2010). Also in the case of the residents of Slovenia the WTP predominantly depends on household income but the willing- 
ness to participate in green electricity programs is influenced by the environmental awareness and education (Zorić and Hrovatin 2012). Income was also the main factor that significantly affected consumer WTP for green energy among the residents of Shanghai: the respondents with medium-to-high level of income were willing to pay more for this type of energy (Vand et al. 2019). The importance of awareness for the differences in the declared WTP between American and Asian households, based on conducted meta-analysis, is also indicated by Soon and Ahmad (2015). The positive influence of income on the WTP is also confirmed by the studies conducted among British society (Batley et al. 2001). However, in the case of the studies conducted among the residents of Sweden, the support for sustainable renewable energy decreased along with age and income (Ek 2005). WTP can be measured not only through the analysis of the declarations concerning paying for energy in households, but also through the analysis of the number of people staying in the hotels using renewable energy sources. As indicated by the survey conducted among tourists staying in Crete, the strong, statistically significant factors that positively influence their willingness to pay for accommodation in a green hotel were, in particular, environmental awareness and information distribution (Kostakis and Sardianou 2012). The factors determining the WTP also include the knowledge related to energy issues and environmental concern (Li et al. 2020; Cai et al. 2019). As displayed by the results of research conducted in China by Tianyu and Meng (Tianyu and Meng 2020) higher education would increase both the WTP amount and the incentive for environmental improvements.

For practical reasons, in research concerning the WTP, participants are not usually asked about the sources for procurement of renewable energy, but this indicator varies depending on such sources. The meta-regression analysis performed by Ma et al. (2015) indicated that people are declaring significantly higher WTP for solar, wind or generic renewable energy sources than for the energy produced from biomass or hydro-energy. In the case of certain energy sources, a negative WTP may even be displayed, such as in the case resulting from the negative social perception of nuclear power following the earthquake of March 11, 2011 in Japan, which led to the catastrophe, which occurred in the Fukushima Daiichi nuclear power plant (Morita and Managi 2015). This catastrophe is perceived as a factor indicating the need for intensifying the development of renewable energy (Ertör-Akyazı et al. 2012; Zhu et al. 2016). As indicated by the studies conducted in the US the level of WTP is also dependent on the payment method - it is higher in the case of the collective payment method than in the case of the voluntary method (Wiser 2007).

The energy from renewable sources constitutes a sort of impure public good (Kotchen 2006) characterized by the joint production of an environmental public good (reduction of greenhouse gas emissions) and a private good (individual consumption of electricity). The aforementioned public good is non-excludable in character i.e. no one can be excluded from drawing benefits from the pressure of climate change lessened through the reduction of greenhouse gas emissions. Expecting such a reduction is one of the major motifs behind the WTP - research among American respondents indicated that they are willing to pay approximately USD 0.30 for a $1 \%$ decrease in greenhouse gases emission (Sundt and Rehdanz 2015). 


\section{Materials and methods}

The interview survey was conducted on a randomly selected representative sample group of 393 residents of Kraków, Poland. Research in the form of direct interviews based on the prepared survey questionnaire was conducted between October 2019 and March 2020. The study was conducted in accordance with the Declaration of Helsinki of 1975 revised in 2013. The research utilized the contingent valuation $(\mathrm{CV})$ method in order to estimate the standard economic value as the respondents' willingness to pay for energy from renewable sources. This is the method used the most frequently in order to establish the WTP (Sundt and Rehdanz 2015). The research sample of residents was selected so as to correspond with the structure of types of housing in Kraków (the adopted division covered the following types of housing: terraced housing, detached housing, tenement houses, low-rise apartment buildings with up to 4 floors, high-rise apartment buildings with 5 or more floors). The survey was conducted with the objective of learning about the opinions of residents concerning conserving energy, the willingness to engage in restorative actions and experienced adverse effects of occurring problems. The respondents were in particular asked about their willingness to pay more for energy, if the energy would come from renewable sources. Questions also concerned their willingness to undertake actions pertaining to the conservation of energy or indicating the factors which were an obstacle to conserving energy. A separate group of questions concerned the assessment of the results of the introduction of the total ban on burning solid fuels in Kraków on the $1^{\text {st }}$ of September 2019, as well as the experienced health consequences of pollution, smog in particular.

The goal of the statistical analysis presented below was to indicate whether gender, the type of housing, the percentage of income devoted to covering electricity bills, the problems with covering electricity bills, the willingness to forgo using a car, the support for the ban on burning solid fuels in Kraków and in the nation, the actions taken in order to conserve energy and the attitude towards the consumption and conservation of energy, are predictors for the WTP.

The linear regression analysis in the mixed model was used to analyze the presented hypothesis. The declared supplementary payment for renewable energy was the dependent variable. All the remaining variables were independent variables. In this manner, it was researched whether these variables properly explained the declared supplementary payment amount for the energy from a renewable source.

The result of the $\mathrm{F}$ test $(14,374)=4.84 ; \mathrm{p}<0,001$ indicate that the model was statistically significant, ergo it properly demonstrated the variability of the analyzed dependent variable (WTP). The detailed analysis indicated a statistically significant influence of the type of housing and the fact of using energy-efficient appliances. In the case of the type of housing, the value of the beta factor was -0.34 . Respondents living in detached houses or terraced houses declared a meaningfully higher amount of supplementary payment for the renewable energy than the residents of apartment buildings or tenement houses. The type of housing also influenced the WTP for green electricity among the residents of the Shanghai region of China (Hast et al. 2015). 
TABLE 1. Definitions and descriptive statistics of the dependent variables and the independent variables

TABELA 1. Definicje i statystyki opisowe zmiennej objaśnianej oraz zmiennych objaśniających

\begin{tabular}{|c|c|c|c|c|c|c|}
\hline $\begin{array}{l}\text { Declared supplementary } \\
\text { payment }\end{array}$ & Amount in PLN & 393 & 83.32 & 116.80 & 0.00 & 750.00 \\
\hline Gender & female $=1 ;$ male $=2$ & 393 & 1.41 & 0.49 & 1.00 & 2.00 \\
\hline Place of residence & $\begin{array}{c}\text { a house }=1 ; \text { block of flats/tenement } \\
\text { house }=2\end{array}$ & 393 & 1.76 & 0.43 & 1.00 & 2.00 \\
\hline Age bracket & $\begin{array}{c}\text { below } 18 \text { years of age }=1 ; \text { more than } \\
60 \text { years of age }=6\end{array}$ & 393 & 3.27 & 1.40 & 1.00 & 6.00 \\
\hline $\begin{array}{l}\text { Electricity bills as } \\
\text { a percentage of income }\end{array}$ & percentage value & 393 & 15.86 & 10.32 & 0.00 & 80.00 \\
\hline $\begin{array}{l}\text { Difficulties with covering } \\
\text { electricity bills }\end{array}$ & $\begin{array}{c}\text { strongly disagree }=1 ; \text { disagree }=2 ; \\
\text { undecided }=3 ; \text { agree }=4 ; \text { strongly } \\
\text { agree }=5\end{array}$ & 393 & 2.18 & 1.11 & 1.00 & 5.00 \\
\hline $\begin{array}{l}\text { Willingness to forgo using } \\
\text { a car }\end{array}$ & $\begin{array}{c}\text { not applicable }=0 ; \text { strongly disagree } \\
=1 ; \text { disagree }=2 ; \text { undecided }=3 ; \\
\quad \text { agree }=4 ; \text { strongly agree }=5\end{array}$ & 393 & 2.32 & 1.64 & 0.00 & 5.00 \\
\hline $\begin{array}{l}\text { Opinion on the ban on } \\
\text { burning solid fuels }\end{array}$ & $\begin{array}{c}\text { strongly disagree }=1 ; \text { disagree }=2 ; \\
\text { undecided }=3 ; \text { agree }=4 ; \text { strongly } \\
\text { agree }=5\end{array}$ & 393 & 3.89 & 1.02 & 1.00 & 5.00 \\
\hline $\begin{array}{l}\text { Support towards the natio- } \\
\text { nal ban on burning solid } \\
\text { fuels }\end{array}$ & $\begin{array}{c}\text { strongly disagree }=1 ; \text { disagree }=2 ; \\
\text { undecided }=3 ; \text { agree }=4 ; \text { strongly } \\
\text { agree }=5\end{array}$ & 393 & 3.53 & 1.22 & 1.00 & 5.00 \\
\hline $\begin{array}{l}\text { Use of energy-efficient } \\
\text { appliances }\end{array}$ & no $=0 ;$ yes $=1$ & 393 & 0.54 & 0.50 & 0.00 & 1.00 \\
\hline Turning off light & no $=0 ;$ yes $=1$ & 393 & 0.85 & 0.36 & 0.00 & 1.00 \\
\hline Disconnecting chargers & no $=0 ;$ yes $=1$ & 393 & 0.50 & 0.50 & 0.00 & 1.00 \\
\hline Thermoregulation & no $=0 ;$ yes $=1$ & 393 & 0.29 & 0.45 & 0.00 & 1.00 \\
\hline $\begin{array}{l}\text { Not opening windows in } \\
\text { winter }\end{array}$ & no $=0 ;$ yes $=1$ & 393 & 0.52 & 0.50 & 0.00 & 1.00 \\
\hline $\begin{array}{l}\text { Attitude towards the use and } \\
\text { conservation of energy }\end{array}$ & $\begin{array}{l}\text { no willingness to act }=0 \text {; willingness } \\
\text { to act }=1\end{array}$ & 393 & 0.57 & 0.50 & 0.00 & 1.00 \\
\hline
\end{tabular}

$\mathrm{N}$ - number; $\mathrm{M}$ - mean; SD - Standard Deviation; Min. - minimal value; Max. - maximum value. Source: own study.

In the case of using energy-efficient appliances, the value of the beta factor was 0.17 . Respondents using energy-efficient appliances declared a meaningfully higher amount of supplementary payment for the renewable energy than the people not using such appliances. The use of energy-efficient appliances is, on the one hand, a sign of a higher environmental awareness and, on the other, requires possession of adequate financial assets.

The corrected conformity coefficient of the entire model was $\mathrm{R} 2=0.11$, which means that the adopted model explained $11.0 \%$ of the variability of the declared supplementary payment. Thus, 
TABLE 2. Regression analysis results

TABELA 2. Wyniki analizy regresji

\begin{tabular}{|l|r|r|r|c|c|c|c|}
\hline \multicolumn{1}{|c|}{ Designation } & \multicolumn{1}{c|}{ SS } & \multicolumn{1}{c|}{ SE } & \multicolumn{1}{c|}{$\beta$} & $\mathrm{df}$ & $\mathrm{F}$ & $\mathrm{p}$ & \\
\hline Model & $815,569.52$ & & & 14 & 4.84 & $<0.001$ & $* * *$ \\
\hline Gender (male - female) & $23,44.23$ & 12.16 & -0.03 & 1 & 0.20 & 0.657 & \\
\hline $\begin{array}{l}\text { Place of residence (a block of flats/ } \\
\text { a tenement house - a detached house) }\end{array}$ & $440,338.68$ & 14.22 & -0.34 & 1 & 37.09 & $<0.001$ & $* * *$ \\
\hline Age bracket & $27,110.36$ & 4.61 & -0.07 & 5 & 0.46 & 0.808 & \\
\hline $\begin{array}{l}\text { Electricity bills as a percentage of } \\
\text { income }\end{array}$ & 57.06 & 0.60 & -0.03 & 1 & 0.00 & 0.945 & \\
\hline $\begin{array}{l}\text { Difficulties with covering electricity } \\
\text { bills }\end{array}$ & $2,580.98$ & 5.56 & -0.02 & 1 & 0.22 & 0.641 & \\
\hline Willingness to forgo using a car & $7,265.46$ & 3.79 & 0.04 & 1 & 0.61 & 0.435 & \\
\hline $\begin{array}{l}\text { Support towards the ban on burning } \\
\text { solid fuels in Kraków }\end{array}$ & $8,791.84$ & 7.35 & -0.05 & 1 & 0.74 & 0.390 & \\
\hline $\begin{array}{l}\text { Support towards a national ban on } \\
\text { burning solid fuels }\end{array}$ & 5.70 & 5.90 & 0.01 & 1 & 0.00 & 0.983 & \\
\hline $\begin{array}{l}\text { Attitude towards the use and } \\
\text { conservation of energy }\end{array}$ & 19.54 & 13.05 & -0.01 & 1 & 0.00 & 0.968 & \\
\hline $\begin{array}{l}\text { Use of energy-efficient appliances } \\
\text { (yes - no) }\end{array}$ & $106,152.63$ & 12.01 & 0.17 & 1 & 8.94 & 0.003 & $* *$ \\
\hline Turning off light (yes - no) & $10,983.36$ & 16.46 & 0.06 & 1 & 0.93 & 0.337 & \\
\hline Disconnecting chargers (yes - no) & $1,264.33$ & 12.18 & 0.01 & 1 & 0.11 & 0.744 & \\
\hline Thermoregulation (yes - no) & $4,432.25$ & 13.16 & 0.05 & 1 & 0.37 & 0.542 & \\
\hline $\begin{array}{l}\text { Not opening windows in winter (yes - } \\
\text { no) }\end{array}$ & $3,200.51$ & 11.98 & -0.03 & 1 & 0.27 & 0.604 & \\
\hline Others & $4,440,000.00$ & & & 374 & & & \\
\hline Corrected R2 & & & & & & & \\
\hline Number of observations & 393 & & & & & & \\
\hline
\end{tabular}

SS - sum of squares; SE - standard error; $\beta$ - the beta factor; $\mathrm{df}$ - degrees of freedom; F - statistics of the test; $\mathrm{p}$ statistical significance.

$* * \mathrm{p}<0,01 ; * * * \mathrm{p}<0,001$

Source: own study.

the type of housing and the use of energy-efficient appliances were the variables, which can be deemed to be statistically significant predictors of WTP. 


\section{Results}

\subsection{The willingness to pay for the energy from renewable sources}

In the analyzed group of residents, the average WTP was PLN 83.7 (approx. USD 21.47) whereby the median is PLN 50 (USD 12.82, with the average USD exchange rate in 2020 of PLN 3.90). Almost one in seven respondents (14.3\%) declared to be not interested in paying more for this type of energy in comparison to the energy from non-renewable sources. The WTP displayed statistically significant differences depending on the type of housing in which respondents lived. In the case of persons living in detached housing or terraced housing the WTP was PLN 152.47 (USD 39.11) on average whereas in the case of residents of apartment buildings or tenement houses it was only PLN 62.11 (USD 15.93). The reasons behind such disparities may be related to the level of income of residents, because prices of detached houses or terraced houses are significantly higher than prices of apartments in apartment buildings or tenement houses, and thus only the more affluent individuals can afford them. The average WTP was slightly lower in the case of women (PLN 81.2, USD 20.83) than the WTP amount declared by men (PLN 87.5, USD 22.44).

\subsection{The attitude towards consumption and conservation of electric energy}

To the question "Do you agree with the following statement - I have problems covering electricity bills?" only 3.3\% of the respondents gave the "Strongly agree" answer and $11.7 \%$ gave the "Agree" answer. Thus, it can be stated that $15 \%$ of the respondents experienced problems with covering electricity bills. $16.5 \%$ of the respondents gave the "undecided" answer which may indicate that, for a portion of people from this group the problem exists although it was rather insignificant, or that it was hard for them to admit to this fact. Nearly a third of the respondents (32.1\%) gave the "Strongly disagree" answer for the aforementioned question and $36.4 \%$ gave the "Disagree" answer.

As many as $56.7 \%$ of respondents declared that they would do more to conserve energy if they knew what could be done. This group can be classified not only as a group interested in the subject of conserving energy but also as a group ready to take actions aimed at reaching this goal. Nearly a fifth (17\%) of the respondents indicated that they trusted that the government will solve the energy problems and more than a fifth of them $(20.1 \%)$ indicated that the manner in which they used electric energy had no influence on the national energy situation. Only approximately one person in 17 (6.1\%) declared that they were not interested in energy-related issues. 
The respondents also had the opportunity to indicate the factors which made conserving energy more difficult for them. The most frequently indicated factors were: comfort $(48.6 \%)$, lack of information (49.1\%) and lack of responsibility (40.2\%). The lack of time for taking such actions was indicated by $40 \%$. What is interesting, the least number of answers $(35.1 \%)$ concerned the need to incur financial expenditures.

\subsection{Air pollution - the consequences and the approach to restorative actions}

Kraków was the first city in Poland where, due to the efforts concerning improving air quality, the total ban on burning coal, wood, and other solid fuels in house boilers, stoves, and fireplaces was introduced on September 1, 2019, which turned to be a pivotal step on the path towards improving the air quality in the city (Traczyk and Gruszecka-Kosowska 2020). The decisively positive attitude towards the aforementioned ban on burning solid fuels was expressed by $31 \%$ of the respondents and a rather positive attitude was expressed by $40.7 \%$. Only $2.3 \%$ of the respondents strongly disagreed with the ban, whereas $9.4 \%$ expressed disagreement (Fig. 1). The introduced ban was assessed largely positively, especially in regards to the fact that the necessity of changing the energy source was frequently connected to additional adaptation and operational expenditures. Furthermore, the residents will probably have to change their habits related to heating because, as indicated by the studies conducted among the resi-

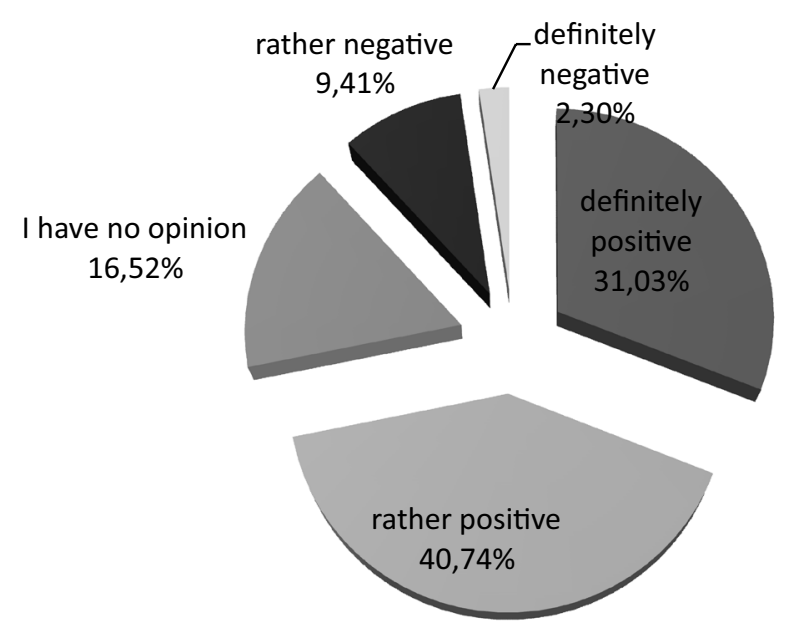

Fig. 1. Attitude to the ban on smoking with solid fuels Source: own study

Rys. 1. Stosunek do zakazu palenia paliwami stałymi 
dents of another Polish city, Wrocław, these habits are related to heating sources (Szulgowska-Zgrzywa et al. 2020). However, Kraków is still characterized by excessive levels of particulate pollutants, largely produced as the result of burning coal in households located in the city's neighboring municipalities, which have not yet introduced such a ban. The appearance of smog is a major problem from the point of view of the residents of Kraków. As many as $29.8 \%$ of the respondents indicated that they strongly experienced its adverse influence on health and $54.5 \%$ also experienced the effects of smog but to a lesser extent. As many as $22.6 \%$ of the respondents strongly agreed with the statement "I have noticed I lose focus when air is heavily polluted" and $38.4 \%$ of respondents indicated that they agreed with the statement. The level of smog also adversely affects the mood of the respondents ( $25 \%$ of the respondents strongly agreed with this statement, $44.8 \%$ agreed).

When asked whether the respondents were concerned with the bills for heating rising due to the ban on burning wood and coal $13.5 \%$ of the respondents answered "definitely yes" and $39.70 \%$ answered "yes". The necessity of changing the source of heating was perceived by more than a half of the respondents as an action increasing their financial burdens but the voices of support for the introduced changes were still dominant.

The declaration of the willingness to resign from owning a car for environmental protection reasons, although it did not have the nature of an obligation, is an indicator of the attitude of a given person towards environmental issues. As many as $8.9 \%$ of the respondents answered that they were definitely willing to resign from using a car and $23.4 \%$ gave the answer that they would be rather willing to do so (Fig. 2).

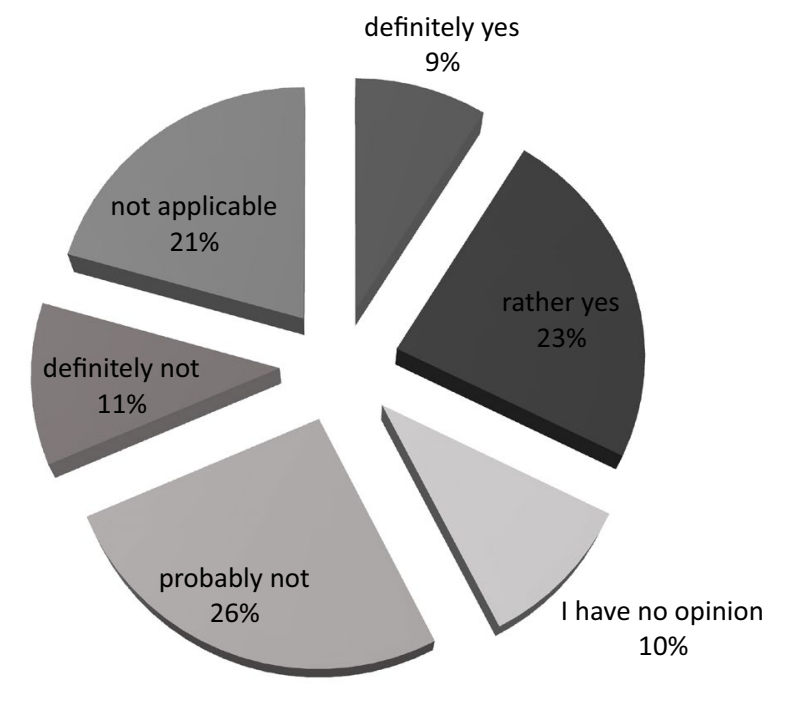

Fig. 2. The declaration of willingness to resign from owning a car for environmental protection reasons Source: own study

Rys. 2. Deklaracja skłonności do rezygnacji z posiadania samochodu ze względu na ochronę środowiska 
The significance of environmental protection for the respondents was also evidenced by the answers given to the question of whether pro-ecological actions were worth the loss of jobs. The question emphasized that it pertained to the issue of shutting down the last blast furnace in the Sędzimir smelter plant in Kraków, widely discussed in the period when the research was conducted. The "definitely yes" answer was given by $10.9 \%$ of respondents and the "yes" answer by $30.5 \%$.

\section{Discussion}

Research conducted among the residents of Kraków showed a high level of support for the ban on burning solid fuels for heating purposes, despite the necessity for bearing adaptation costs related to changing the form of heating as well as the higher charge for the energy from alternative sources. This support can be connected to the common acknowledgement of the adverse influence of pollutants on health (Tainio et al. 2020) as well as to the negative effects of pollution experienced by respondents. Owing to the strong position of Poland in the field of extraction of hard coal, this non-renewable fuel still constitutes a popular source of thermal energy in households which, due to the existence of boilers and stoves not meeting environment protection standards, results in the problem of poor air quality related to low-stack emissions, also in the area of Kraków (Kunecki et al. 2020). The problems with air pollution in Kraków began to emerge as early as the 1950s, mainly as the result of developing industry, particularly due to the existence of the iron smelter plant located in the city - the largest in the country, at that time. Despite the actions taken to improve air quality since the political system transformation was initiated in 1989, even by 2019 severe air pollution, particularly in winter, still constitutes one of the more significant development problems of the city (Romańczyk 2018). Simultaneously, a low level of air pollution is considered a major determinant of the quality of life in the city and a prerequisite for the development of the Business Process Outsourcing and Offshoring sector crucial for the labor market in Kraków (Mamica 2021). As disruptive events have a positive impact on the number of renewable energy policies (Emam et al. 2020) states of high exceedance of pollution norms in Krakow may constitute an impulse for taking radical measures.

The average WTP declared by the residents of Kraków was PLN 83.7 (approx. USD 21.47) i.e. almost three times higher than the average WTP calculated on the basis of the meta-analysis of 30 studies from 13 countries published on or after the year 2000 and estimated at USD 7.16 (Soon and Ahmad 2015). It can be assumed that such a high WTP value was influenced by the high level of air pollution in Kraków and its adverse influence on health experienced and declared by the respondents. Higher values of WTP were displayed, for instance, in the studies conducted in Spain where this indicator reached the value of EUR 29.91 (USD 41.56) (Hanemann et al. 2011) or the United States where it reached approximately USD 44 (Li et al. 2009). 
The WTP declared by the residents of Kraków differs in a statistically significant manner depending on the type of housing in which respondents reside. The residents of detached houses or terraced housing declared on average twice higher WTP value than the residents of apartment buildings or tenement houses (PLN 152.47 i.e. USD 39.11 in comparison to PLN 62.11, i.e. USD 15.93). As the cost of purchasing or renting a detached house or a terraced house is higher than renting an apartment in a block of flats or a tenement house, it may be assumed that in this case the WTP was indirectly related to the level of income. The research results correspond with the results of the survey conducted among the residents of Crete, where WTP increased along with the increase in family income and residence size (Zografakis et al. 2010) or with the results of the studies conducted in Slovenia where WTP also increased along with increased income (Zorić and Hrovatin 2012). The usable floor area in detached and terraced housing is, on average, larger than in the apartments in apartment buildings and tenement houses. The studies conducted among the residents of Kraków displayed that the WTP value is higher among people declaring use of energy-efficient appliances. Using such appliances is indirectly related to the level of awareness of the actions pertaining to environmental protection (Han et al. 2020) and is a display of energy-saving behaviors positively correlated with education (Zhao et al. 2019). Thus the research results are convergent with the works identifying the occurrence of dependence of WTP on knowledge related to energy issues and environmental concern (Li et al. 2020; Cai et al. 2019).

\section{Limitations and policy recommendations}

The respondents possessed varied levels of information on the subject of environmental protection and the costs of producing energy from different types of sources. The varied level of information influence the WTP value and may slightly distort the produced research results (Venkatachalam 2004). The higher the level of knowledge pertaining to the commodity to be evaluated, the lower the level of hypothetical bias in the contingent valuation method (Whitehead and Cherry 2007).

Promoting the significance of willingness to bear the increased costs of purchasing energy from renewable sources should be accompanied by promoting low carbon solutions which, as proposed by Biresselioglu et al., in terms of public perception should be treated as symbols of attractiveness and sophistication (Biresselioglu et al. 2020). Taking the results of the presented studies, which indicate that the WTP increases along with the increased value of the type of housing or apartment into consideration (a fact, which can be indirectly interpreted as the level of wealth), a social campaign should be conducted with the goal of increasing the value of pro-environmental actions. At the same time, important steps in this context should be taken to improve energy efficiency (Lin et al. 2019) as the costs of domestic hot water preparation and heating are a significant component of the overall cost of maintaining apartments costs (Bartnicki and Nowak 2020). In Polish conditions temporary solution for improving the quality of air 
could also be a replacement of hard coal by briquettes, which are characterized by significantly lower emissions, it is $52 \%$ on average (Dziok and Penkała 2020). The strategy of communicating with residents should focus first on the potential benefits for the local community and then on the benefits for the climate (Busch and McCormick 2014). It could be also included in the city's sustainable development plan which contributes to a larger goal of urban sustainability (Moscovici et al. 2015). As in other similar pro environmental actions benefits from such initiatives can be multiplied by greater coordination (Hecht and Sanders Iii 2007). An information campaign is necessary because some household, similarly as in Sweden, can reject transformation because of financial considerations (Palm and Tengvard 2011). In the case of solar panels installed on the roofs of detached houses, which are visible to neighbors, the positive aspect of the psychological pressure directed at persons who did not install such sources of renewable energy should be utilized. The message should be clear - installing such panels is a sign of taking responsibility for the environment and, by the same token, it presents an opportunity for displaying own material wealth. Simultaneously the promotion of decarbonization, energy saving strategies and mitigation measures for greenhouse gas emissions should be supported. In Polish conditions temporary solution for improving the quality of air could also be the replacement of hard coal by briquettes, which are characterized by significantly lower emissions, it is $52 \%$ on average (Dziok and Penkała 2020). In order to reduce the consumption of energy by households an information campaign concerning the practical potentialities of such actions should be carried out. Such actions are justified by the fact that as many as $56.7 \%$ of the respondents declared that they would do more in order to save energy if they knew what to do, and nearly a half of the respondents (49.1\%) indicated the lack of information on the subject as the factor, which made saving energy more difficult for them. The knowledge pertaining to the level of WTP is significant for the process of shaping the level of subsidization for the development of the renewable energy sector. Under the current energy policy, the expenditures which individual consumers are willing to bear in order to convert to the use of renewable energy, should not be substituted but, instead, supported if they are insufficient for such conversion to occur or when such conversion would proceed too slowly.

Funding: This research was funded by the Ministry of Science and Higher Education within the "Regional Initiative of Excellence” Program for 2019-2022. Project No.: 021/RID/2018/19. Total funding: PLN 11,897,131.40.

\section{References}

Bartnicki, G. and Nowak, B. 2020. The gas fuel market in Poland and the costs of final heat generated in a local boiler house. Polityka Energetyczna - Energy Policy Journal 23(2), pp. 105-122, DOI: $10.33223 /$ epj/123218.

Batley et al. 2001 - Batley, S.L., Colbourne, D., Fleming, P.D. and Urwin, P. 2001. Citizen versus consumer: challenges in the UK green power market. Energy Policy 29(6), pp. 479-487, DOI: 10.1016/ S0301-4215(00)00142-7.

Bigerna, S. and Polinori, P. 2014. Italian households' willingness to pay for green electricity. Renewable and Sustainable Energy Reviews 34, pp. 110-121, DOI: 10.1016/j.rser.2014.03.002.

130 
Biresselioglu et al. 2020 - Biresselioglu, M.E., Demir, M.H., Demirbag, K.M. and Solak, B. 2020. Individuals, collectives, and energy transition: Analysing the motivators and barriers of European decarbonisation. Energy Research \& Social Science 66, p. 101493, DOI: 10.1016/j.erss.2020.101493.

Busch, H. and McCormick, K. 2014. Local power: exploring the motivations of mayors and key success factors for local municipalities to go 100\% renewable energy. Energ Sustain Soc 4(1), DOI: 10.1186/2192-0567-4-5.

CAI et al. 2019 - CAI, S., Long, X., Li, L., Liang, H., WANG, Q. and Ding, X. 2019. Determinants of intention and behavior of low carbon commuting through bicycle-sharing in China. Journal of Cleaner Production 212, pp. 602-609, DOI: 10.1016/j.jclepro.2018.12.072.

Comello et al. 2018 - Comello, S., Reichelstein, S. and Sahoo, A. 2018. The road ahead for solar PV power. Renewable and Sustainable Energy Reviews 92, pp. 744-756, DOI: 10.1016/J.RSER.2018.04.098.

Dogan, E. and Muhammad, I. 2019. Willingness to pay for renewable electricity: A contingent valuation study in Turkey. The Electricity Journal 32(10), p. 106677, DOI: 10.1016/j.tej.2019.106677.

Dziok, T. and Penkala, K. 2020. The possibility of reducing emissions from households by using coal briquettes. Polityka Energetyczna - Energy Policy Journal 23(3), pp. 55-70, DOI: 10.33223/epj/126438.

EIA 2019. International Energy Outlook 2019. Energy Information Administration. Washington, DC, USA.

EK, K. 2005. Public and private attitudes towards "green" electricity: the case of Swedish wind power. Energy Policy 33(13), pp. 1677-1689, DOI: 10.1016/j.enpol.2004.02.005.

Emam et al. 2020 - Emam, S., Grebel, T. and Tudor, A.-D. 2020. Do we need disasters to adopt more environmental policies? Energ Sustain Soc 10(1). DOI: 10.1186/s13705-020-00256-3.

Ertör-Akyazi et al. 2012 - Ertör-Akyazi, P., Adaman, F., ÖZkaynak, B. and ZenginobuZ, Ü. 2012. Citizens' preferences on nuclear and renewable energy sources: Evidence from Turkey. Energy Policy 47, pp. 309-320, DOI: 10.1016/j.enpol.2012.04.072.

Guo et al. 2014 - Guo, X., Liu, H., MaO, X., Jin, J., Chen, D. and Cheng, S. 2014. Willingness to pay for renewable electricity: A contingent valuation study in Beijing, China. Energy Policy 68, pp. 340-347, DOI: 10.1016/j.enpol.2013.11.032.

Halkos, G.E. and Gkampoura, E.-C. 2020. Reviewing Usage, Potentials, and Limitations of Renewable Energy Sources. Energies 13(11), p. 2906, DOI: 10.3390/en13112906.

Han et al. 2020 - Han, M.S., BiYIng, Y., Cudjoe, D. and Yuan, Q. 2020. Investigating willingness-to-pay to support solar energy research and development in Myanmar. Energy Policy 146, p. 111820, DOI: 10.1016/j.enpol.2020.111820.

Han, M.S. and CudjoE, D. 2020. Determinants of energy-saving behavior of urban residents: Evidence from Myanmar. Energy Policy 140, p. 111405, DOI: 10.1016/j.enpol.2020.111405.

Hanemann et al. 2011 - Hanemann, M., Labandeira, X. and Loureiro, M.L. 2011. Climate change, energy and social preferences on policies: exploratory evidence for Spain. Clim. Res. 48(2), pp. 343-348, DOI: $10.3354 / \mathrm{cr} 00994$

Hast et al. 2015 - Hast, A., Alimohammadisagvand, B. and Syri, S. 2015. Consumer attitudes towards renewable energy in China - The case of Shanghai. Sustainable Cities and Society 17, pp. 69-79, DOI: 10.1016/j.scs.2015.04.003.

Hecht, A.D. and SANDERS III, W.H. 2007. How EPA research, policies, and programs can advance urban sustainability. Sustainability: Science, Practice and Policy 3(2), pp. 37-47, DOI: 10.1080/15487733.2007.11908001.

Hertzberg et al. 2017 - Hertzberg, M., Siddons, A. and Schreuder, H. 2017. Role of greenhouse gases in climate change. Energy \& Environment 28(4), pp. 530-539.

Hess, D.J. and Gentry, H. 2019. 100\% renewable energy policies in U.S. cities: strategies, recommendations, and implementation challenges. Sustainability: Science, Practice and Policy 15(1), pp. 45-61, DOI: $10.1080 / 15487733.2019 .1665841$. 
IPCC 2014. Summary for Policymakers. [In:] Edenhofer, O., R. Pichs-Madruga, Y. Sokona, E. Farahani, S. Kadner, K. Seyboth, A. Adler, I. Baum, S. Brunner, P. Eickemeier, B. Kriemann, J. Savolainen, S. Schlömer, C. von Stechow, T. Zwickel and J.C. Minx (eds) (Ed.): Climate change 2014. Mitigation of climate change: IPCC Working Group III contribution to AR5. Potsdam, Germany: IPCC Working Group III, pp. 1-30.

JIN et al. 2019 - JiN, J., Wan, X., Lin, Y., KUANG, F. and NING, J. 2019. Public willingness to pay for the research and development of solar energy in Beijing, China. Energy Policy 134, p. 110962, DOI: 10.1016/j.enpol.2019.110962.

Kaenzig et al. 2013 - Kaenzig, J., Heinzle, S.L. and Wüstenhagen, R. 2013. Whatever the customer wants, the customer gets? Exploring the gap between consumer preferences and default electricity products in Germany. Energy Policy 53, pp. 311-322, DOI: 10.1016/j.enpol.2012.10.061.

Kashintseva et al. 2018 - Kashintseva, V., Strielkowski, W., Streimikis, J. and Veynbender, T. 2018. Consumer Attitudes towards Industrial $\mathrm{CO}_{2}$ Capture and Storage Products and Technologies. Energies 11(10), p. 2787, DOI: 10.3390/en11102787.

Kim et al. 2020 - Kıм, S.-M., Kim, J.-H. and Yoo, S.-H. 2020. Households' Willingness to Pay for Substituting Natural Gas with Renewable Methane: A Contingent Valuation Experiment in South Korea. Energies 13(12), p. 3082, DOI: 10.3390/en13123082.

Kostakis, I. and SARdianou, E. 2012. Which factors affect the willingness of tourists to pay for renewable energy? Renewable Energy 38(1), pp. 169-172, DOI: 10.1016/j.renene.2011.07.022.

Kotchen, M.J. 2006. Green Markets and Private Provision of Public Goods. Journal of Political Economy 114(4), pp. 816-834. DOI: 10.1086/506337.

Kunecki et al. 2020 - KuneCKI, P., Franus, W. and Wdowin, M. 2020. Statistical study and physicochemical characterization of particulate matter in the context of Kraków, Poland. Atmospheric Pollution Research 11(3), pp. 520-530, DOI: 10.1016/j.apr.2019.12.001.

Levitan et al. 2014 - Levitan, O., Dinamarca, J., Hochman, G. and Falkowski, P.G. 2014. Diatoms: a fossil fuel of the future. Trends in Biotechnology 32(3), pp. 117-124, DOI: 10.1016/j.tibtech.2014.01.004.

Li et al. 2009 - Li, H., Jenkins-Smith, H.C., Silva, C.L., Berrens, R.P. and Herron, K.G. 2009. Public support for reducing US reliance on fossil fuels: Investigating household willingness-to-pay for energy research and development. Ecological Economics 68(3), pp. 731-742, DOI: 10.1016/j.ecolecon.2008.06.005.

Li et al. 2020 - Li, L., Long, X., LAUBaYeva, A., CAI, X. and ZHU, B. 2020. Behavioral intention of environmentally friendly agricultural food: the role of policy, perceived value, subjective norm. Environmental science and pollution research international 27(15), pp. 18949-18961, DOI: 10.1007/s11356-020$-08261-\mathrm{x}$.

Lim et al. 2017 - Lim, S.-Y., KIm, H.-J. and Yoo, S.-H. 2017. Public's willingness to pay a premium for bioethanol in Korea: A contingent valuation study. Energy Policy 101, pp. 20-27, DOI: 10.1016/j. enpol.2016.11.010.

Lin et al. 2019 - Lin, R., LiU, Y., Man, Y. and ReN, J. 2019. Towards a sustainable distributed energy system in China: decision-making for strategies and policy implications. Energ Sustain Soc 9(1), DOI: 10.1186/s13705-019-0237-9.

Lu, W.-C. 2017. Greenhouse Gas Emissions, Energy Consumption and Economic Growth: A Panel Cointegration Analysis for 16 Asian Countries. In International journal of environmental research and public health 14(11). DOI: 10.3390/ijerph14111436.

Ma et al. 2015 - Ma, C., Rogers, A.A., Kragt, M.E., Zhang, F., Polyakov, M., Gibson, F. et al. 2015. Consumers' willingness to pay for renewable energy: A meta-regression analysis. Resource and Energy Economics 42, pp. 93-109, DOI: 10.1016/j.reseneeco.2015.07.003. 
Mamica, Ł. 2018. Public Policy and the Neo-Weberian State. [In:] Stanisław Mazur, Piotr Kopycinski (Eds.): Public policy and the neo-Weberian state. Abingdon, Oxon, New York, NY: Routledge, an imprint of the Taylor \& Francis Group (Routledge frontiers of political economy, 235), pp. 110 -119 .

MamicA, Ł. ed. 2021. Outsourcing in European emerging economies. Territorial embeddedness and global business services. Abingdon, Oxon, New York, NY: Routledge (Routledge advances in regional economics, science and policy).

Marra et al. 2012 - Marra, A.E., Jensen, K.L., Clark, C.D., English, B.C. and Toliver, D.K. 2012. Greenhouse gas emission reductions as a motivator of e85 purchases across market segments. Energ. Sustain. Soc. 2(1), DOI: 10.1186/2192-0567-2-21.

Morita, T. and Managi, S. 2015. Consumers' willingness to pay for electricity after the Great East Japan Earthquake. Economic Analysis and Policy 48, pp. 82-105, DOI: 10.1016/j.eap.2015.09.004.

Moscovici et al. 2015 - Moscovici, D., Dilworth, R., Mead, J. and ZhaO, S. 2015. Can sustainability plans make sustainable cities? The ecological footprint implications of renewable energy within Philadelphia's Greenworks Plan. Sustainability: Science, Practice and Policy 11(1), pp. 32-43, DOI: 10.1080/15487733.2015.11908137.

Navrud, S. and Bråten, K.G. 2007. Consumers' preferences for green and brown electricity: a choice modelling approach. Revue d'économie politique 117(5), pp. 795-811.

Oerlemans et al. 2016 - Oerlemans, L.A.G.; Chan, K.-Y. and Volschenk, J. 2016. Willingness to pay for green electricity: A review of the contingent valuation literature and its sources of error. Renewable and Sustainable Energy Reviews 66, pp. 875-885, DOI: 10.1016/j.rser.2016.08.054.

Palm, J. and Tengvard, M. 2011. Motives for and barriers to household adoption of small-scale production of electricity: examples from Sweden. Sustainability: Science, Practice and Policy 7(1), pp. 6-15, DOI: 10.1080/15487733.2011.11908061.

Pleeging et al. 2020 - Pleeging, E., van Exel, J., Burger, M.J. and Stavropoulos, S. 2020. Hope for the future and willingness to pay for sustainable energy. Ecological Economics, p. 106900, DOI: 10.1016/j. ecolecon.2020.106900.

RAY, D. 2019. Lazard's Levelized Cost of Energy Analysis - Version 13.0. Lazard: New York, NY, USA, p. 20.

RomańCZYK, K.M. 2018. Krakow - The city profile revisited. Cities 73, pp. 138-150, DOI: 10.1016/j. cities.2017.09.011.

Shen et al. 2020 - Shen, N., Deng, R., Liao, H. and Shevchuk, O. 2020. Mapping renewable energy subsidy policy research published from 1997 to 2018: A scientometric review. Utilities Policy 64, p. 101055.

Soon, J.-J. and Ahmad, S.-A. 2015. Willingly or grudgingly? A meta-analysis on the willingness-to-pay for renewable energy use. Renewable and Sustainable Energy Reviews 44, pp. 877-887, DOI: 10.1016/j. rser.2015.01.041.

Sundt, S. and ReHDanz, K. 2015. Consumers' willingness to pay for green electricity: A meta-analysis of the literature. Energy Economics 51, pp. 1-8, DOI: 10.1016/j.eneco.2015.06.005.

Szulgowska-Zgrzywa et al. 2020 - Szulgowska-Zgrzywa, M., Stefanowicz, E., Piechurski, K., Chmielewska, A. and KowalczYK, M. 2020. Impact of Users' Behavior and Real Weather Conditions on the Energy Consumption of Tenement Houses in Wroclaw, Poland: Energy Performance Gap Simulation Based on a Model Calibrated by Field Measurements. Energies 13(24), p. 6707, DOI: 10.3390/ en13246707.

Tainio et al. 2020 - Tainio, M., Jovanovic Andersen Z., Nieuwenhuissen, M.J., Hu, L., Nazelle, A. $\mathrm{DE} ; \mathrm{AN}, \mathrm{R}$. et al. 2020. Air pollution, physical activity and health: A mapping review of the evidence. Environment international 147, p. 105954, DOI: 10.1016/j.envint.2020.105954. 
Tianyu, J. and Meng, L. 2020. Does education increase pro-environmental willingness to pay? Evidence from Chinese household survey. Journal of Cleaner Production 275, p. 122713, DOI: 10.1016/j.jclepro.2020.122713.

Traczyk, P. and Gruszecka-Kosowska, A. 2020. The Condition of Air Pollution in Kraków, Poland, in 2005-2020, with Health Risk Assessment. International journal of environmental research and public health 17(17), DOI: 10.3390/ijerph17176063.

TranciK, J.E. and Cross-CALL, D. 2013. Energy technologies evaluated against climate targets using a cost and carbon trade-off curve. Environmental science \& technology 47(12), pp. 6673-6680, DOI: 10.1021/es304922v.

VAND et al. 2019 - VAnd, B., HASt, A., Bozorg, S., Li, Z., Syri, S. and Deng, S. 2019. Consumers' Attitudes to Support Green Energy: A Case Study in Shanghai. Energies 12(12), p. 2379, DOI: 10.3390/ en12122379.

Venkatachalam, L. 2004. The contingent valuation method: a review. Environmental Impact Assessment Review 24(1), pp. 89-124, DOI: 10.1016/S0195-9255(03)00138-0.

Vossler et al. 2003 - Vossler, C.A., Ethier, R.G., Poe, G.L. and Welsh, M.P. 2003. Payment certainty in discrete choice contingent valuation responses: results from a field validity test. Southern Economic Journal, pp. 886-902.

WhiteheAD, J.C. and CHERrY, T.L. 2007. Willingness to pay for a Green Energy program: A comparison of ex-ante and ex-post hypothetical bias mitigation approaches. Resource and Energy Economics 29(4), pp. 247-261, DOI: 10.1016/j.reseneeco.2006.10.001.

WISER, R.H. 2007. Using contingent valuation to explore willingness to pay for renewable energy: A comparison of collective and voluntary payment vehicles. Ecological Economics 62(3-4), pp. 419-432, DOI: $10.1016 /$ j.ecolecon.2006.07.003.

Woo et al. 2019 - Woo, J.R., Chung, S., Lee, C.-Y. and Huh, S.-Y. 2019. Willingness to participate in community-based renewable energy projects: A contingent valuation study in South Korea. Renewable and Sustainable Energy Reviews 112, pp. 643-652, DOI: 10.1016/j.rser.2019.06.010.

Zhang et al. 2019 - Zhang, C., Wang, Q., Zeng, S., Baležentis, T., Štreimikienė, D., Ališauskaitė -ŠEŠKIENE, I. and CHEN, X. 2019. Probabilistic multi-criteria assessment of renewable micro-generation technologies in households. Journal of Cleaner Production 212, pp. 582-592, DOI: 10.1016/j. jclepro.2018.12.051.

Zhao et al. 2019 - Zhao, X., Cheng, H., Zhao, H., Jiang, L. and Xue, B. 2019. Survey on the households' energy-saving behaviors and influencing factors in the rural loess hilly region of China. Journal of Cleaner Production 230, pp. 547-556, DOI: 10.1016/j.jclepro.2019.04.385.

Zhu et al. 2016 - Zhu, H., Deng, Y., Zhu, R. and He, X. 2016. Fear of nuclear power? Evidence from Fukushima nuclear accident and land markets in China. Regional science and urban economics 60, pp. 139-154, DOI: 10.1016/j.regsciurbeco.2016.06.008.

Zografakis et al. 2010 - Zografakis, N., Sifaki, E., Pagalou, M., Nikitaki, G., Psarakis, V. and TsagaRAKIS, K.P. 2010. Assessment of public acceptance and willingness to pay for renewable energy sources in Crete. Renewable and Sustainable Energy Reviews 14(3), pp. 1088-1095.

Zorić, J. and Hrovatin, N. 2012. Household willingness to pay for green electricity in Slovenia. Energy Policy 47, pp. 180-187, DOI: 10.1016/j.enpol.2012.04.055. 


\title{
Skłonność do płacenia za energię ze źródeł odnawialnych deklarowana przez mieszkańców Krakowa w perspektywie działań zmierzających do obniżenia poziomu zanieczyszczenia środowiska
}

\begin{abstract}
Streszczenie
Przeprowadzenie transformacji energetycznej w kierunku szerszego wykorzystywania źródeł odnawialnych jest jednym z kluczowych zadań na drodze do zahamowania negatywnych zmian klimatycznych. Tempo tego procesu zależy zarówno od decyzji politycznych, jak i poparcia społecznego dla wdrażanych zmian. Wskaźnikiem wspomnianego poparcia jest skłonność do płacenia za energię ze źródeł odnawialnych (ang. Willingness to pay for Renewable Energy Sources WTP), deklarowana przez mieszkańców. Celem niniejszego artykułu jest analiza determinant tej skłonności na przykładzie mieszkańców Krakowa oraz postrzegania przez nich działań redukujących poziom zanieczyszczeń środowiska w oparciu o wyniki badań ankietowych przeprowadzonych na reprezentatywnej grupie 393 mieszkańców tego miasta. Badania uwzględniają opinie dotyczące wprowadzenia od 1 września 2019 roku pionierskiego w skali Polski zakazu palenia paliwami stałymi. W analizowanej grupie mieszkańców średnia miesięczna skłonność do płacenia więcej za energię pochodzącą ze źródeł odnawialnych wyniosła 83,7zł, tj. ok. 21,47 USD. WTP różni się od siebie w statystyczne istotny sposób w zależności od typu zabudowy, w jakiej mieszkają ankietowani. Mieszkańcy domów jednorodzinnych lub domów w zabudowie szeregowej deklarują średnio ponad dwukrotnie wyższą wartość WTP niż mieszkańcy bloków i kamienic (odpowiednio 152,47 zł, tj. 39,11 USD w stosunku do 62,11 zł, tj. 15,93 USD). Przeprowadzone badania pokazały również, że wartość WTP jest w sposób statystycznie istotny determinowana przez fakt wykorzystywania urządzeń energooszczędnych, i wyższa w grupie osób deklarujących ich stosowanie.
\end{abstract}

SŁOWA KLUCZOWE: skłonność do zapłaty za energię odnawialną, transformacja energetyczna, postawy ekologiczne, polityka energetyczna 
